\title{
ANALISIS PENGHAPUSAN PIDANA MALAPRAKTIK TENAGA KESEHATAN DITINJAU DARI UNDANG-UNDANG NOMOR 36 TAHUN 2009
}

\author{
Syaldiva Canda Sari \& Sigit Handoko \\ Universitas PGRI Yogyakarta \\ syaldiva01@gmail.com
}

\begin{abstract}
Abstrak
Penelitian ini bertujuan untuk mengetahui alasan dari penghapusan pidana malapraktik tenaga kesehatan ditinjau dari Undang-Undang Nomor 36 Tahun 2009 tentang Kesehatan. Metode yang digunakan dalam penelitian ini adalah Metode Penelitian Studi Literatur yaitu dengan menggunakan studi keperpustakaan. Pemaparan hasil data penelitian menggunakan studi analisis sesuai dengan tujuan penelitian dalam pembahasan. Analisis data yang digunakan dalam penelitian ini adalah deskriptif serta objektif. Hasil penelitian disimpulkan bahwa analisis penghapusan pidana malapraktik ditinjau dari undang-undang nomor 36 tahun 2009 tentang Kesehatan yaitu pada Pasal 29 UU Nomor 36 Tahun 2009 menyatakan bahwa tindakan tenaga kesehatan yang melakukan kelalaian diselesaikan melalui mediasi. Undang- Undang Nomor 36 tahun 2009 tidak secara limitatif mengakomodir bahwa malapraktik sebagai bagian dari tindak pidana, melainkan hanya sebagai malapraktik hukum dan malapraktik etik. Begitupun dalam KUHP tidak diatur secara kontekstual mengenai malapraktik, yang diatur di KUHP adalah perbuatan yang berhubungan dengan nyawa orang atau perbuatan menyakiti tubuh orang. Apabila semua kewajiban dan perilaku tenaga kesehatan dalam melaksanakan pelayanan medis tidak menyimpang dari tata kelakuan yang ditetapkan oleh kode etik profesinya, serta kewajiban secara administrasi telah terpenuhi, maka dokter bersangkutan yang diduga melakukan malapraktik tidak dapat dituntut di hadapan Majelis Kode Etik Kedokteran (MKEK). Pertanggungjawaban tenaga kesehatan menurut hukum pidana harus dilihat dari perbuatannya terlebih dulu. Sesuai Pasal 50 dan Pasal 51 ayat (1) dan (2) KUHP, tenaga kesehatan yang melaksanakan undang-undang sesuai kode etik profesi dan melaksanakan perintah jabatan maka tidak dapat dipidana, alasan tersebut menjadi dasar untuk menghapus pidana perbuatan dokter atau tenaga kesehatan.
\end{abstract}

Kata Kunci : Malapraktik, Kesehatan

\begin{abstract}
The reseach puspose is to know the reason the criminal elimination of malpractice of healthcare personnel reviewed from Law Number 36 Year 2009 About Health. The research method used Literature Study Research Method that was by using. Data result presentation used analysis study approptiate with the research purpose in the discussion. Data analysis used descriptive and objective. The results of the study concluded that analysis the removal of criminal malapraktik in terms of the Law Number 36 Year 2009 About health where the article 29 Law Number 36 Year 2009 stated that the act of paramedics who do omission solved through mediation. The Law Number 36 Year 2009 About Health does not have a limitation on the basis of malpractice as part of criminal acts, but only as a malpractice of law and malpractice of ethic. KUHP is not setting about the malpractice, which is governed by the KUHP is a deed related to the lives of people or deeds hurt the body. If all the obligations and behaviors of healthcare personnel in carrying out medical services do not deviate from the conduct prescribed by the Code of conduct, as well as the obligation of the administration has been fulfilled, then the Doctor who is suspected of doing malpractice can not be claimed to the Majelasi Medical Code (MKEK). Accountability health workers according to criminal law should be seen from his first. In accordance with the article 50 and article 51 paragraph (1) and (2) KUHP, paramedics who carrying out the laws in accordance code of conduct a profession and do the injunction of the job according of the office, that reason be the foundation for remove criminal what a doctor or health workers .
\end{abstract}

Key words: Malpractice, Health. 


\section{PENDAHULUAN}

Indonesia adalah Negara berdasarkan atas hukum. Sebagai negara hukum Indonesia menjamin kelangsungan hidup setiap kehidupan warga negaranya. Setiap warga negara dijamin hak asasinya di mana semua warga negara di mata hukum adalah sama. Indonesia sebagai negara hukum dijelaskan dalam Undang-Undang Dasar 1945 Pasal 1 Ayat (3) yang berbunyi Negara Indonesia adalah negara hukum. Sebagai negara hukum Indonesia wajib menjamin masyarakatnya dari tindakan yang melanggar hukum disegala aspek kehidupan seperti di bidang politik, ekonomi, pendidikan, sosial, dan bidang kesehatan dan dituntut untuk taat hukum dan disiplin dalam kehidupan bermasyarakat dan bernegara (Nurgiansah \& Widyastuti, 2020).

Di Indonesia, masalah perselisihan medis selalu dikaitkan dengan malapraktik. Istilah malapraktik ini sebenarnya tidaklah tepat dan tidak dikenal dalam sistem tata hukum Indonesia, dan dari hasil pengembangan hukum kesehatan dalam sistem tata hukum di Indonesia, istilah yang digunakan adalah kesalahan atau kelalaian dalam menjalankan kewajiban profesional atau disebut dengan kelalaian profesi medis atau dalam istilah hukum pidana dikenal dengan medical malpractice. Medical malpractice dapat diartikan sebagai suatu tindakan kesalahan atau kelalaian yang dilakukan oleh dokter dalam melaksanakan kewajiban profesional, tidak sesuai dengan tujuan pelayanan medis yakni mengurangi penderitaan, memperpanjang kehidupan, dan mendampingi pasien sampai akhir kehidupannya, dan tujuan hukum pidana untuk memberikan perlindungan terhadap kejahatan tubuh dan nyawa seseorang.

Dalam hukum yang berlaku di Indonesia yaitu kitab undang- undang hukum pidana mengenai tindakan yang mengakibatkan meninggalnya seseorang atau terluka karena kesalahan, kealpaan masuk dalam rumusan Pasal 359, 360, dan 361 Kitab Undang-Undang Hukum Pidana dan dalam Undang-Undang Nomor 36 tahun 2009 tentang Kesehatan. Dengan diundangkannya Undang- Undang Nomor 36 Tahun 2009 tentang Kesehatan yang secara tegas dalam Pasal 29 menyatakan: dalam hal tenaga kesehatan diduga melakukan kelalaian dalam menjalankan profesinya, kelalaian tersebut harus diselesaikan melalui mediasi. Mengingat bahwahak asasi manusia dan ketertiban hukum yang harus ditegakkan, kasus malapraktik yang perlu dipertanggung jawabkan namun pidana yang ada dihapuskan, maka dalam penelitian ini diharapkan mampu menjunjung tinggi nilai hukum serta Hak Asasi Manusia.

\section{METODE PENELITIAN}

Penelitian ini menggunakan metode literatur untuk mendapatkan data dengan tujuan tertentu dan menggunakan bukubuku sebagai bahan bacaan untuk mencapai tujuan dan memeperoleh kegunaan yang bersifat rasional, empiris, dan sistematis. Rasional berarti kegiatan itu dilakukan dengan cara yang masuk akal, sehingga terjangkau oleh penalaran manusia. Empiris berarti cara-cara yang dilakukan itu dapat diamati oleh indera manusia. Sehingga orang lain dapat mengamati dan mengetahui cara-cara yang digunakan. Sistematis artinya proses yang digunakan dalam penelitian itu menggunakan langkah-langkah tertentu yang bersifat logis.

Ruang lingkup pada penelitian ini yang berjudul "Analisis Penghapusan Pidana Malapraktik Tenaga Kesehatan Ditinjau Dari Undang-Undang Nomor 36 Tahun 2009" akan dibatasi pada pembahasan tentang dasar dan alasan penghapusan pidana malapraktik tenaga kesehatan menurut undang- undang nomor 36 tahun 2009, namun demikian tidak 
berarti dalam penelitian ini akan mengabaikan hal-hal yang terjadi sebelum dan bahkan sesudahnya terhadap masalah yang ada hubungannya dan kaitannya dengan judul tersebut.

Pengumpulan sumber data menggunakan sumber primer dan sumber sekunder (Sugiyono, 2017:137). Pemilihan sumberdidasarkan pada empat aspek yakni:(1) Provenance (bukti), yakni aspek kredensial penulis dan dukungan bukti, misalnya sumber utama sejarah; (2) Objectivity (Objektifitas), yakni apakah ide perspektif dari penulis memiliki banyak kegunaan atau justru merugikan; (3) Persuasiveness (derajat keyakinan), yakni apakah penulis termasuk dalam golongan orang yang dapat diyakini; dan (4) Value (nilai kontributif), yakni apakah argumen penulis meyakinkan, serta memiliki kontribusi terhadap penelitian lain yang signifikan (Farisi, 2012:72).

Pengumpulan sumber untuk judul ini berupa dokumen, buku, jurnal, dan peraturan perundang-undangan untuk menemukan suatu peristiwa atau kasus malapraktik guna menemukan temuan yang baru untuk judul. Mengumpulkan sumber memiliki fungsi sebagai cara untuk membandingkan suatu peristiwa dan informasi yang ada, menemukan ilmu baru untuk temuan selanjutnya, menambah referensi yang digunakan untuk memperluas informasi. Kritik sumber bertujuan untuk memastikan bahwa sumber yang dipakai adalah sumber yang otentik. Secara sederhana langkah ini akan memastikan bahwa sumber yang dipakai adalah tepat, dari kritik sumber akan dilakukan pengamatan keaslian sumber. Berdasarkan sumber yang telah ditemukan, sumber buku dan jurnal membantu penulis dalam mengerjakan penelitian. Data yang ditemukan dari buku dan jurnal diantaranya Hukum Pidana Malapraktik Pertanggungjawaban dan Penghapus Pidana, Tanggung Jawab Pidana
Para Medis Terhadap Tindakan Malpraktek Menurut Undang-Undang Nomor 36 Tahun 2009 Tentang Kesehatan, dan lain sebagainya.

Interpretasi merupakan tahapan yang harus dilalui oleh peneliti sebelum menuangkan data dan fakta yang diperoleh menjadi sebuah bentuk tulisan. Pada tahap ini peneliti melakukan penafsiran terhadap fakta yang sudah ada melalui sebuah tahap kritikan. Setelah itu menghubungkan hal tersebut untuk memperoleh gambaran secara mendalam mengenai dasar dan alasan penghapusan pidana malapraktik menurut hukum pidana berdasarkan undang-undang nomor 36 tahun 2009. Historiografi merupakan sarana mengkomunikasikan fakta masa lalu yang disusun secara tulisan berupa cerita sehingga mudah untuk dipahami.

\section{HASIL PENELITIAN DAN PEMBAHASAN Hasil Penelitian}

Menurut Kamus Besar Bahasa Indonesia (KBBI) hukum pidana adalah hukum yang menentukan peristiwa perbuatan kriminal yang diancam dengan pidana. Hukum pidana adalah salah satu sub sistem hukum yang ada di suatu negara, ada dua istilah yaitu hukum dan pidana. Hukum menurut Prof.Dr. Van Kan Hukum adalah keseluruhan peraturan hidup yang bersifat memaksa untuk melindungi kepentingan dalam masyarakat. Pidana terdapat beberapa pengertian menurut para ahli. Menurut Profesor Van Hamel pidana atau straf adalah : "Suatu penderitaan yang bersifat khusus, yang telah dijatuhkan oleh kekuasaan yang berwenang untuk menjatuhkan pidana atas nama negara sebagai penanggungjawab dari ketertiban hukum umum bagi seorang pelanggar, yakni semata-mata karena orang tersebut telah melanggar suatu peraturan hukum yang harus ditegakkan oleh negara (Lamintang, 2002:47). 
Istilah hukum pidana merupakan terjemah dari istilah bahasa Belanda strafrecht straf berarti pidana, dan recht berarti hukum. Menurut Wirjono Prodjodikirono bahwa istilah hukum pidana itu dipergunakan sejak pendudukan Jepang di Indonesia untuk pengertian strafrecht dari bahasa Belanda, dan untuk membedakannya dari istilah hukum perdata untuk pengertian burgerlijkrecht atau privaatrecht dari bahasa Belanda.

Menurut Prof. Satochid Kartanegara mengemukakan bahwa hukuman pidana adalah sejumlah peraturan yang merupakan bagian dari hukum positif yang mengandung larangan-larangan dan kekuasaan lain yang berwenang untuk menemukan peraturan pidana, larangan atau keharusan itu disertai ancaman pidana, dan apabila hal ini dilanggar timbullah hak negara untuk melakukan tuntutan, menjatuhkan pidana, melaksanakan pidana (Amir Ilyas, 2012:2).

Hukum pidana dalam kasus malapraktik digunakan apabila timbul akibat berupa kematian atau cacatnya seseorang. Hukum pidana berperan sebagai hukum sanksi. Apabila terjadi suatu kematian atau cacat setelah suatu perawatan oleh dokter atau tenaga medis lainnya, untuk membuktikan sejauh mana terjadinya kesalahan maka harus dibuktikan melalui hukum pidana, meskipun tidak selamanya permasalahan akan dapat diselesaikan melalui hukum pidana (Elvandari, 2015:60).

Malapraktik bermula karena adanya kesalahan, baik secara etika maupun secara hukum, yang keduanya dilakukan secara berbarengan. Untuk menentukan ada tidaknya kesalahan berupa sengaja atau kelalaian dalam malapraktik, tindakan pertama dilakukan adalah dengan melihat standar profesi melalui kode etik kedokteran. Tindakan hukum pada malapraktik dipergunakan sebagai bagian akhir atau ultimum remedium (penerapan sanksi pidana yang merupakan sanksi pamungkas atau terakhir dalam penegakan hukum). Kesalahan merupakan unsur yang perlu untuk menentukan dapat tidaknya seorang dijatuhi pidana, begitu pula dalam malapraktik, ditentukan oleh ada tidaknya kesalahan dokter dalam melakukan tindakan medis terhadap pasien, baik secara etik kedokteran maupun secara hukum (Hiariej, 2012:25).

Menurut Mudakir Iskandarsyah, malapraktik secara medik adalah kelalaian dokter untuk mempergunakan tingkat keterampilan dan ilmu pengetahuan berdasarkan ukuran yang lazim orang lain dalam mengobati pasien untuk ukuran standar di lingkungan yang sama. Kelalaian diartikan pula dengan melakukan tindakan kedokteran di bawah standar pelayanan medik (Iskandarsyah, 2011:1). Veronika menyatakan, bahwa malapraktik berasal dari kata malpractice yang pada hakikatnya adalah kesalahan dalam menjalankan profesi yang timbul sebagai akibat adanya kewajiban-kewajiban yang harus dilakukan dokter.

Medical malpractice adalah kesalahan dalam menjalankan profesi medik yang tidak sesuai dengan standar profesi medik dalam menjalankan profesinya (Kumalawati, 2002:87). Malapraktik secara medis adalah kelalaian seorang dokter menggunakan tingkat ketrampilan dan ilmu pengetahuan berdasarkan ukuran yang lazim orang lain dalam mengobati pasien dengan ukuran standar di lingkungan yang sama. Kelalaian diartikan pula dengan melakukan tindakan kedokteran di bawah standar pelayanan medik (Iskandarsyah, 2019:1).

Hukum pidana mengenal perbedaan antara peniadaan pidana dengan dasar penghapusan penuntutan. Peniadaan pidana ditetapkan oleh hakim dengan menyatakan, bahwa sifat melawan hukumnya perbuatan hapus atau kesalahan pembuat hapus, karena adanya 
ketentuan undang-undang dan hukum yang membenarkan perbuatan atau yang memaafkan pembuat. Hak menuntut dari jaksa tetap ada, namun terdakwa tidak dapat dijatuhi pidana, sedangkan peniadaan penuntutan pidana menghapuskan hak untuk menuntut bagi jaksa, karena adanya ketentuan undangundang (Muntaha, 2017:110).

Dasar peniadaan pidana di luar undang-undang, dalam hal ini KUHP, meliputi yang merupakan alasan pembenar (tidak adanya unsur melawan hukum) dan alasan pemaaf (tidak adanya kesalahan). Alasan pembenar merupakan segi luar dari pembuat atau faktor objektif dan alasan pemaaf dari segi subjektif. Van Hamel menyatakan bahwa dasar pembenar adalah penghapus dasar melawan hukum, sedangkan yang lain menghapuskan (hal pantas dipidana) (Muntaha, 2017:334).

Undang-undang kesehatan kepastian hukum dan perlindungan hukum untuk meningkatkan, mengarahkan dan memberikan dasar bagi pembangunan kesehatan. Penegakan hukum menurut Barda Nawami Arief adalah menegakkan nilai-nilai kebenaran dan keadilan di sini, bahwa penegak hukum dipercaya oleh masyarakat untuk menegakkan nilai-nilai kebenaran dan keadilan yang terkandung di dalam hukum (Arief, 2008:23).

Undang-Undang No 36 Tahun 2009 mengatur tentang Kesehatan dalam rangka implementasi paradigma sehat, dibutuhkan undang-undang yang berwawasan sehat dan undang- undang berwawasan sakit yaitu Undang-Undang No 44 Tahun 2009 tentang Rumah Sakit. Undang-Undang tentang Kesehatan dan Rumah Sakit akan menjadi aturan yang digunakan untuk upaya meningkatkan derajat kesehatan masyarakat. Undang- Undang tersebut memuat ketentuan yang menyatakan bahwa bidang kesehatan sepenuhnya diserahkan kepada daerah diberi kewenangan daerah masing-masing yang setiap daerah diberi kewenangan untuk mengelola dan menyelenggarakan seluruh aspek kesehatan.

Malapraktik merupakan suatu kasus yang ada di bidang kesehatan yang kemudian menjadi konflik hukum sehingga perlu dibahas dan dianalisis secara hukum sesuai Undang-Undang yang berlaku. Persamaan penelitian oleh Suwari Akhmaddhian Fakultas Hukum Universitas Kuningan dengan jurnalnya, Jurnal Unifikasi, ISSN 2354- 5976 Volume 1 Nomor 1 pada Oktober 2013 yang berjudul "Analisis Pertanggung Jawaban Tenaga Kesehatan yang melakukan Tindak Pidana Malpraktek menurut Kitab Undang-Undang Hukum Pidana dan Undang-Undang Nomor 36 Tahun 2009 tentang Kesehatan" dengan penelitian ini adalah menganalisis tindak pidana malapraktik tenaga kesehatan menurut Undang-Undang Nomor 36 Tahun 2009 tentang Kesehatan.

Perbedaannya adalah Suwari Akhmad dhian menganalisis pertanggung jawaban tenaga kesehatan yang melakukan tindak pidana malapraktik menurut Kitab Undang-Undang Nomor 36 Tahun 2009, sedangkan penelitian ini menganalisis penghapusan pidana malapraktik tenaga kesehatan ditinjau dari Undang- Undang Nomor 36 Tahun 2009. Persamaan penelitian oleh Santika Domopolii Jurnal Lex Crimen Volume VI/ Nomor 6/ Agustus/ 2017 yang berjudul "Tanggung Jawab Pidana Para Medis Terhadap Tindakan Malpraktek Menurutu Undang- Undang Nomor 36 Tahun 2009 tentang Kesehatan" dengan penelitian ini adalah membahas mengenai tenaga kesehatan yang melakukan tindakan malapraktik menurut Undang- Undang Nomor 36 Tahun 2009. Perbedaannya adalah Santika Domopolii membahas mengenai tanggung jawab tenaga kesehatan yang melakukan malapraktik menurut Hukum Pidana dan tanggung jawab para tenaga medis terhadap tindakan malapraktik menurut 
Undang-Undang Nomor 36 Tahun 2009, sedangkan penelitian ini membahas mengenai penghapusan pidana malapraktik tenaga kesehatan ditinjau dari UndangUndang Nomor 36 Tahun 2009.

\section{Pembahasan}

Pertanggung jawaban pidana terhadap seorang tenaga kesehatan yang melakukan tindak pidana malapraktik dapat dikemukakan bahwa pertanggung jawaban pidananya terletak pada kesalahan yang berupa kealpaan dan kelalaian ketika tenaga kesehatan tersebut menjalankan profesinya. Akibat dari kesalahan tenaga kesehatan tersebut mengakibatkan kematian atau luka-luka, unsur kesalahan yang dilakukan tenaga kesehatan dalam hal ini adalah kelalaian berat yang akan dimintakan pertanggung jawaban dari akibat yang timbul dari perbuatannya. Ketentuan tentang penghapusan pidana KUHP diatur dalam Buku I tentang Aturan Umum, yakni dalam Pasal 44 yang mengatur tentang kemampuan bertanggung jawab, Pasal 48 tentang daya paksa, Pasal 49 tentang pembelaan terpaksa, Pasal 50 tentang pelaksanaan ketentuan undang-undang, dan Pasal 51 tentang pelaksanaan perintah jabatan. Alasan penghapus pidana dalam teori hukum pidana dapat dibedakan menjadi tiga macam:

1. Alasan pembenar, yaitu alasan yang menghapuskan sifat melawan hukumnya perbuatan sehingga apa yang dilakukan oleh terdakwa lalu menjadi perbuatan yang patut dan benar.

2. Alasan pemaaf, yaitu alasan yang menghapuskan kesalahan terdakwa. Perbuatan yang dilakukan oleh terdakwa tetap bersifat melawan hukum, jadi tetap merupakan perbuatan pidana, akan tetapi tidak dapat dipidana karena tidak ada kesalahan.

3. Alasan penghapus penuntutan, di sini persoalannya bukan ada alasan pembenar maupun alasan pemaaf, jadi tidak ada pikiran mengenai sifatnya perbuatan maupun sifatnya orang yang melakukan perbuatan, akan tetapi, penegak hukum menganggap bahwa atas dasar atau kemanfaatan kepada masyarakat, sebaiknya tidak diadakan penuntutan menjadi pertimbangan di sini adalah kepentingan umum, jika perkaranya tidak dituntut, tentunya yang melakukan perbuatan tidak dapat dijatuhi pidana.

Alasan penghapus pidana dalam malapraktik dapat dilihat dalam dua aspek, yaitu aspek yang berkaitan dengan etika profesi dokter. Aspek ini, titik beratnya diletakkan pada pelanggaran sumpah dokter, pelanggaran kode etik kedokteran (KODEKI), serta pelanggaran- pelanggaran kewajiban dokter yang tercantum di dalam, baik pada Undang- Undang Nomor 36 Tahun 2009 tentang Kesehatan maupun pada Undang- Undang Nomor 29 Tahun 2004 tentang Praktik Kedokteran serta peraturan perundang-undangan lainnya. Apabila semua kewajiban dan perilaku dokter dalam melaksanakan pelayanan medis tidak menyimpang dari tata kelakuan yang ditetapkan oleh kode etik profesinya, serta kewajiban secara administrasi telah terpenuhi, maka dokter yang bersangkutan yang diduga melakukan malapraktik tidak dapat dituntut di hadapan Majelis Kode Etik Kedokteran (MKEK), dalam arti bahwa tindakan dokter tersebut sesuai dengan standar profesi.

Selanjutnya aspek yang berkaitan dengan hukum. Dokter tidak hanya melakukan pelayanan medis dalam kedudukannya sebagai pribadi, melainkan juga dapat melakukan pelayanan medis dalam kedudukannya sebagai wakil pada suatu institusi publik. Dalam kedudukan sebagai pribadi, apabila melakukan suatu tindakan medis yang melanggar ketentuan yang berlaku, maka dokter yang 
bersangkutan dapat dituntut suatu pertanggungjawaban secara hukum, baik itu menyangkut hukum perdata, maupun hukum administrasi, maupun hukum pidana, pada kedudukannya sebagai yang mewakili institusi dapat dilihat pada dua sisi : Sebagai pelaksana dari suatu perintah undang- undang, di mana dokter tersebut diperintahkan oleh ketentuan undangundang untuk melaksanakan suatu tindakan medis dan secara ukuran normal perintah undang-undang itu bertentangan dengan etika profesi serta hukum (Pasal 50 KUHP). Adanya perintah jabatan, di mana seorang dokter yang bekerja sebagai pegawai negeri, yang ditugaskan oleh atasannya untuk melakukan suatu tindakan medis terhadap seseorang, secara etik dan hukum dapat dikatakan bertentangan, tetapi demi kepentingan yang lebih besar, maka perbuatan yang dilakukan dokter yang bersangkutan tidak dapat dipidana.

Dilakukannya perbuatan atas alasan karena melaksanakan ketentuan undangundang dan perintah jabatan dasar untuk menghapus pidana bagi perbuatan dokter tersebut (Pasal 51 ayat (1) dan (2) KUHP). Analisis berdasarkan Tesa, Antitesa, Sintesa. Tesanya adalah Undang- Undang Nomor 36 Tahun 2009 Tahun 2009 Pada Pasal 24 Ayat (1) Tenaga kesehatan sebagaimanadimaksud dalam Pasal 23 harus memenuhi ketentuan kode etik, standar profesi, hak pengurus pelayanan kesehatan, standar pelayanan dan standar prosedur operasional. Pasal 24 Ayat (2) Ketentuan mengenai kode etik dan standar profesi sebagaimana dimaksud pada ayat (1) diatur oleh organisasi profesi. Pasal 29 "Dalam hal tenaga kesehatan diduga melakukan kelalaian dalam menjalankan profesinya, kelalaian tersebut harus diselesaikan melalui mediasi".

Antitesanya, Kitab Undang- Undang Hukum Pidana pada Pasal 359, 360, dan 361 menerangkan tentang hukuman bagi orang yang karena kesalahannya mengakibatkan orang mati atau luka. Pasal 50 KUHP "Barang siapa melakukan perbuatan untuk menjalakan peraturan undang- undang, tidak boleh dihukum. Pasal 51 Ayat (1) Barang siapa melakukan perbuatan untuk menjalankan perintah jabatan yang diberikan oleh kuasa yang berhak akan itu, tidak boleh dihukum. Alasan tersebut menjadi dasar untuk menghapus pidana perbuatan dokter atau tenaga kesehatan.Sintesanya, jadi, tenaga kesehatan atau dokter dalam menjalankan tugasnya harus sesuai dengan standar profesinya, memenuhi kode etiknya, jika terjadi kelalaian dalam menjalankan tugas profesinya, maka tenaga kesehatan tersebut akan diselidiki kasusnya terlebih dahulu, dalam masa penyelidikan oleh pihak berwenang terlebihdahulu tenaga kesehatan maupun korban atau keluarga korban menyelesaikan dulu melalui mediasi.

Pada saat penyelidikan terbukti bahwa ada malapraktik yang dilakukan dokter maka akan lebih diteliti lagi apakah dokter dalam menjalankan tugas profesinya memenuhi syarat pertama, sudah menjalankan tugas profesinya secara profesional sesuai dengan kode etik profesinya, kedua dokter tersebut sedang melakukan undang-undang yang berlaku atau tidak, ketiga dokter tersebut sedang menjalankan perintah jabatan atau tidak, keempat penyebab dokter harus melakukan tindakan medis apakah ada suatu yang darurat pada pasien atau tidak sebelumnya. Syarat tersebut sebagai patokan pihak berwajib dalam menangani kasus malapraktik, namun pada realitanya kasus malapraktik sulit diselidiki karena Undang-Undang Nomor 36 tahun 2009 dan KUHP tidak secara kontekstual mengakomodir kasus malapraktik serta alasan penghapusan pidana malapraktik atau keterbatasan mengenai aturan kasus malapraktik. Pemerintah diharapkan 
merevisi KUHP dan UU No 36 Tahun 2009 tentang Kesehatan supaya secara tegas lebih rinci pengaturan malapraktik baik tindakan malapraktik, pertanggug jawabannya, serta penghapusan pidananya.

\section{KESIMPULAN}

Berdasarkan hasil pembahasan dapat disimpulkan bahwa, Analisis Penghapusan Pidana Malapratik Tenaga Kesehatan ditinjau dari Undang-Undang Nomor 36 Tahun 2009 tentang Kesehatan yaitu pada Pasal 29 yang menyatakan bahwa "Dalam hal tenaga kesehatan diduga melakukan kelalaian dalam menjalankan profesinya, kelalaian tersebut harus diselesaikan terlebih dahulu dengan mediasi". UndangUndang Nomor 36 tahun 2009 tidak secara limitatif mengakomodir bahwa malapraktik sebagai bagian dari tindak pidana, melainkan hanya sebagai malapraktik hukum dan malapraktik etik. Begitupun dalam KUHP tidak diatur secara kontekstual mengenai malapraktik, yang diatur di KUHP adalah perbuatan yang berhubungan dengan nyawa orang atau perbuatan menyakiti tubuh orang.

Apabila semua kewajiban dan perilaku tenaga kesehatan dalam melaksanakan pelayanan medis tidak menyimpang dari tata kelakuan yang ditetapkan oleh kode etik profesinya, serta kewajiban secara administrasi telah terpenuhi, maka dokter bersangkutan yang diduga melakukan malapraktik tidak dapat dituntut di hadapan Majelis Kode Etik Kedokteran (MKEK). Pertanggungjawaban tenaga kesehatan menurut hukum pidana harus dilihat dari perbuatannya terlebih dulu. Sesuai Pasal 50 dan Pasal 51 ayat (1) dan (2) KUHP, tenaga kesehatan yang melaksanakan undang-undang sesuai kode etik profesi dan melaksanakan perintah jabatan maka tidak dapat dipidana, alasan tersebut menjadi dasar untuk menghapus pidana perbuatan dokter atau tenaga kesehatan.

Berdasarkan hasil dari penelitian Analisis Penghapusan Pidana Malapraktik Tenaga Kesehatan ditinjau dari UndangUndang Nomor 36 Tahun 2009 terdapat beberapa saran yang perlu untuk diperhatikan terkait dengan permasalahan. Saran- saran tersebut antara lain: Untuk tenaga kesehatan terutama dokter, dalam melakukan suatu tindakan medis perlu adanya informasi terlebih dahulu kepada pasien, diperlukan kehati-hatian dalam melakukan diagnosis supaya untuk memutuskan suatu tindakan selanjutnya tidak terjadi malapraktik, perlu adanya hubungan yang berasaskan perikemanusiaan Serta dalam melaksanakan tindakan harus sesuai dengan aturan undangundang yang berlaku.

Bagi Pemerintah, Dalam penerapan pasal-pasal yang ada kurang jelas pengertian unsur kelalaian yang menjadi ukuran apakah tenaga kesehatan melakukan kelalaian atau tidak dalam menjalankan profesinya, dengan keterbatasan peraturan mengenai malapraktik, pemerintah diharapkan merevisi KUHP dan undang-undang kesehatan supaya peraturannya akan lebih rinci, tegas, dan kontekstual khusus tindakan malapraktik, pertanggung jawabannya, serta penghapusan pidananya.

Bagi Masyarakat, untuk masyarakat yang merupakan penerima pelayanan kesehatan diharapkan untuk mencari tahu informasi kesehatan, meminta kejelasan dari dokter atau tenaga kesehatan lain, dan memikirkan secara matang dalam memutuskan menerima tindakan dokter supaya dapat memahami segala pengambilan keputusan medis sehingga mengerti dan menyadari manfaat serta resiko dari tindakan medis.

\section{DAFTAR PUSTAKA}


Akhmaddhian, Suwari. 2013. "Analisis Pertanggung Jawaban Tenaga Kesehatan yang melakukan Tindak Pidana Malpraktek menurut Kitab Undang-Undang Hukum Pidana dan Undang-Undang Nomor 36 tahun 2009 tentang Kesehatan". Unifikasi, Vol1(1), 34-49.

Arief, Barda Nawawi. 2008. Masalah Penegakan Hukum Pidana dalam Penanganan Kejahatan. Jakarta: Kencana Media Group.

Damopolii, Sartika. 2017. “Tanggung Jawab Pidana Para Medis Terhadap Tindakan Malpraktek Menurut Undang-Undang Nomor 36 Tahun 2009 Tentang Kesehatan "Jurnal Hukum, Vol I(1)

Elvandari, Siska. 2015. Hukum Penyelesaian Sengketa Medis. Yogyakarta: Thafa Media.

Hiariej, Eddy O.S. 2012. Teori dan Hukum Pembuktian. Jakarta: Erlangga.

Ilyas, Amir. 2012. Asas-Asas Hukum Pidana Memahami Tindak Pidana Dan Pertanggung jawaban Pidana Sebagai Syarat Pemidanaan. In Rangkang Education Yogyakarta \& PuKAP- Indonesia.

Iskandarsyah, Mudakir. 2011. Tututan Pidana dan Perdata Malpraktik. Jakarta: Permata Aksara

Kumalawati, Veronika. 2002. Hukum dan Etika Dalam Praktik Dokter. Jakarta: Sinar Harapan. Lamintang, P. A 2002. Hukum Penitensier Indonesia. Bandung: Amrico.

Muntaha. 2017. Hukum Pidana Malapraktik Pertanggungjawaban dan Penghapus Pidana. Jakarta Timur: Sinar Grafika.

Nurgiansah, T. H., \& Widyastuti, T. M. (2020). Membangun Kesadaran Hukum Mahasiswa PPKn UPY Dalam Berlalu Lintas. Civic Edu: Jurnal Pendidikan Kewarganegaraan Universitas Pasundan, 2(2), 97-102. https://doi.org/10.1017/CB09781107415324.004

Sugiyono. 2017. Metode Penelitian. Bandung: IKAPI. Kumalawati, Veronika. 2002. Hukum dan Etika Dalam Praktik Dokter. Jakarta: Sinar Harapan.

Siregar, Fitria Lubis \& Amry S. 2020. "Analisis Penghapusan Pidana Terhadap Perbuatanmenghilangkan Nyawa Orang Lain Karena Alasan Adanya Daya Paksa (Overmacht)". Retenrum, 2020(02), 9-17. (Online) 